\title{
Fear of crime and the role of the police
}

\author{
L.E. Mayoyo' \\ Mthatha, Eastern Cape \\ P.J. Potgieter ${ }^{2}$ \\ Department of Criminal Justice, University of Zululand \\ p.potgieter@telkomsa.net \\ J.M. $\operatorname{Ras}^{3}$ \\ Department of Criminal Justice, University of Zululand \\ jras@pan.uzulu.ac.za
}

\begin{abstract}
Social values such as safety and security needs of members of society are necessary to ensure a sustainable quality of life for all; guaranteed and protected by the Constitution. If this envisaged tranquility is disturbed or negatively affected by crime and fear of crime resulting from criminal victimisation, then both crime and fear crime become public concerns. The study presents two focal points: crime and fear of crime as well as the role of the police, which all exert a significant influence on the lives of citizens. Criminal victimisation may cause physical harm, feelings of anxiety, emotional instability, mistrust of the formal control structure, alienation, etc., that promotes fear of crime. Such factors may result in a break of social cohesion, curtailment of daily activities and withdrawal from society. Policing, on the other hand, personifies social order and the guaranteed protection of people in a manner consistent with democratic principles. A non-parametric survey research method, incorporating a closed-structured questionnaire has been implemented to capture data from two arbitrarily selected Eastern Cape samples: Mthatha and Butterworth, primarily to explore and describe perceptions pertaining to crime, fear of crime and the role of the police in terms of gender $(N=300)$. Gender is an appropriate predictor of fear of crime. Having rated seven selected serious crimes, female respondents are significantly more fearful of criminal victimisation than their male counterparts. Cooperation with the police to report and prevent crime, call upon them in emergency situations, etc., is on a sound footing, with females virtually outnumbering the males in all those functions. This finding is further vouched for by the fact that females had more positive and less negative 'police contact' compared to male respondents. Improved police-public relations and dedicated police service delivery will become more and more inevitable.
\end{abstract}

Keywords: Crime, Police, South Africa

\section{Introduction}

Fear of crime is one of the more adverse social and psychological consequences of crime, leading to anxiety, mistrust in the criminal justice system (police, courts and corrections), social disruption and the deterioration of the quality of community and social life in general. When crime takes place the mass media would, in most instances, be the first agent to focus on the victims' pain and suffering, material losses (motor vehicle, cash, cell phone, etc.), and perhaps the emotional and psychological traumatisation they had to endure during their ordeal (Mayoyo 2009:I). These observations are what Moore and Trojanowicz (1988:I-18) referred to as the concrete signs of criminal victimisation. Following recovery from a criminal attack, victims usually accept their fate in a spirit of 'being lucky to be alive', or 'just having been in the wrong place at the wrong time', etc. However, subjacent to the concrete impact of criminal victimisation, fear of criminal harassment may persist long after the real harm caused to victims took its course. For instance, xenophobic attacks on foreigners from neighboring countries such as Zimbabwe, Malawi, Nigeria, Kenya and Mozambique, not only reverberated throughout the South African socio-political spectrum, but also drew attention from people in overseas countries that vehemently condemned such deviant behavior (The Mercury 2008:I). During that time, more than fifty innocent people (believed to be foreigners), were either set alight and burnt to death or killed with knob sticks or other dangerous weapons (kangaroo court-style). Fear of further criminal harassment eventually forced some crowds to take refuge in a Johannesburg Methodist Church (The Star 2008:3). In juridical sense, the police are directly or indirectly part and parcel of the crime and fear of crime equation, brought about by the type of contact respondents had with their local police and, among other, a willingness to report crime to the police when they are personally victimised, their willingness

I. L.E. Mayoyo is a Retired Police Officer, Mthatha, Eastern Cape, South Africa

2. P.J. Potgieter, DPhil, is a Research Fellow, University of Zululand, South Africa. He was Professor and Head of the Department of Criminal Justice at the same University for several years.

3. Johan Ras, DPhil, is Associate Professor and Head of the Department of Criminal Justice at the University of Zululand, South Africa. 
to prevent crime, or to assist the police in this endeavour, and whether respondents feel at liberty to lodge a complaint at a police station, etc. (Van Velzen 1998: 199-200; Mayoyo 2009:131-133).

\section{Rationale for the study}

With the exception of a few studies into different dimensions of people's fear of crime, e.g. Glanz (cf. 1989) and Van Velzen (cf. 1998), measurement of this phenomenon in South Africa appears to be still inadequate. This may be ascribed to the fact that criminals' modus operandi may vary over time and space or criminals may become more and more brutal and sophisticated. Despite all the rhetoric around several crime prevention plans recently released by members of political parties, the African National Congress (ANC) contended that “... there is general public discontent with the government's inability to curb violent crime" (The Times 2008:I2). It also transpires that no study into the concrete influence of policing in reducing fear of crime among law abiding citizens has been undertaken in the Eastern Cape during the past decades. The primary aim of the present study resides, therefore, primarily in bridging the gap in our substantive knowledge of and insight into fear of crime in the Eastern Cape. The notion of police presence, calculated to create the illusion of omnipresence and feelings of safety and security among people is added to this discussion to better understand the underlying dynamics of policing in both proactive (crime prevention) and reactive (law enforcement) contexts (Lyman 2003:6). The prevalence of fear of crime, mainly among the female respondents in the two Eastern Cape towns, forms the basis of the research question of the present study. A brief exposition of the research design, which facilitated the analysis and description of the research problem, fear of crime, is discussed below.

\section{Conceptualisation}

Concepts are described or highlighted purely to exploit their relevance to the social phenomenon being investigated. It also creates an opportunity to eliminate any possible confusion which may arise from interpreting the meaning of each concept.

\section{Crime}

Briefly, crime has a dual meaning: in juridical sense, it refers to a violation of the law for which the state (courts) may impose a punishment; in criminological terms, crime includes all forms of criminal acts as well as deviant behaviour that are not necessarily regarded juridical in nature (Van der Westhuizen 1977:38). The present study relies on the juridical definition of crime.

\section{Crime prevention}

Crime prevention simply points to the elimination of the opportunities that may exist to precipitates criminal actions leading to crime commission. The police, through their role visibility (or omnipresence), together with the active involvement of members of the community as co-producers of safety and security, should serve as capable 'agents' to prevent or at least reduce crime.

\section{Fear and fear of crime}

Physiologically, fear alerts the human body against potential danger (cf. Van Velzen 1998) that may create feelings of anger, outrage, frustration and powerlessness. Fear of crime becomes more specific when it points to the anticipation of the occurrence of one or other criminal event that may result in the potential of being victimised. Researchers usually distinguish between formless and concrete fear of crime. Formless fear points to an observation and subsequent perception of being vulnerable to criminal acts, either in terms of a physical, socio-economic nature or a general feeling of being not safe, while concrete fear entails a perceived risk of victimisation and the type of crime likely to take place or fear of specific crimes (e.g. murder, rape, hijacking, etc.) (cf. Van Velzen 1998).

\section{Police and policing}

Van Heerden (1982:13) conveniently informs us that the term police originally derives from the Greek words polis (city) and polites (citizen of the state), the Latin word politea (state authority), and the French word policer (power of the people). The word police officially received recognition in Ireland round about I787, but only in I829, did Sir Robert Peel establish his first organised police better known as the Bow Street Runners (Van Heerden 1982:25-26). In modern terms, police refer to individuals appointed by law (statute) to maintain law and order and to ensure the protection of human rights under the Constitution. Policing has a more functional meaning, “... the personification of [social] order and a guarantee that the constitutional rights of every individual ... will be protected ..." (Van Heerden 1982: 15).

\section{Policing and fear of crime}

More than two decades ago, Mark Moore and Robert Trojanowicz (1988: I-18) wrote an informative monograph on fear of crime and policing on behalf of the National Institute of Justice (NIJ), suggesting that whenever crime occurs, it does not take place in isolation. Usually, people directly or indirectly get involved with crime victims and/or their families Inkanyiso, Jnl Hum \& Soc Sci 20I I, 3(I) 
through sympathising with them because their "... wounds, bruises, lost property, and inconvenience can be seen, touched and counted" (Moore \& Trojanowicz 1988:I). People who fall prey to criminals, fear crime because of its impact on their lives as victims; the lasting effect of such feelings may remain with them for years. People who have been victimised may even decide to move to other places because of their fear that their assailants may return (which often happens). Irrespective of rape victims being traumatised emotionally and psychologically, the criminal justice process often engage in plea bargaining with criminals without any real input from the victims. Criminal trials are often protracted for too long (Lyman 2003:2; 12). It further transpires that forensic criminal investigations as well as the absence of a proper scientific DNA profiling system in serious criminal cases like rape, murder, etc. are still not fully functional in South Africa (Rapport 2010:6).

Fear of crime may not be totally counterproductive, because its positive effects may be observed in: (a) citizens who have been inspired to become more cautious about their safety by minimising crime precipitants, (b) people who may decide to share ideas relating to mechanical crime prevention (installation of locks and electronic alarms, erecting concrete walls around properties, etc)., and (c) people who are inspired to support the police in crime prevention initiatives, e.g. by attending Community Police Forum (CPF) meetings and interacting more regularly with police officers and even volunteering to be appointed as police reservists.

\section{Research design}

Research design is "... the blueprint according to which data are to be collected to investigate the research hypothesis or [research] question in the most economical manner" (Huysamen 1994:10-I I). A research design depends on two pillars: designing and planning. Design (in the present context) refers to the vital decisions the researcher has to make when 'planning' a research inquiry. The idea of designing a research project is of utmost importance in a structured social survey like attitude measurement. It suffices to say that the research design in the present inquiry encompasses all the phases of the research process without which the research outcomes would have been seriously flawed.

The present study is based on a typical general scientific research approach with positivistic undertones, primarily to allow for the quantification, analysis, interpretation and explanation of statistical outcomes relating to the fear of crime and perceptions about the police role. This approach suggests that "... the same approach applicable to studying and explaining physical reality can be used in social sciences" (Hagan 2000:19). Positivism actually refers to positivistic or philosophical epistemology (theory of knowledge underlying the nature of social phenomena) and the ontology (the philosophical view of the 'world as it is'), which could be established, among other, through attitude measurement (Alant, Lamont, Maritz \& Van Eeden 1981: 199).

A quantitative research approach has been followed in the present study and takes the form of non-parametric statistical analyses to summarise (quantify) data and describe relationships/associations forthcoming from respondents' perceptions and attitudes towards the referent object. Other important research techniques which need to be briefly put into perspective are: the literature study, survey instrument and measuring scale, sampling, statistical tests, data management, etc.

Academic textbooks dealing with fear of crime, policing issues and crime prevention, supported by scientific research articles, existing research reports contained in dissertations and theses, have been consulted to gain a better understanding of the present research question. A great deal of effort has also been devoted to consulting the written media, especially newspapers, to provide greater clarity of the referent object. In particular, written media hype, is being regarded the most widely image-producing sources creating public impressions and perceptions - positive or negative about police performances and criminal events and fear of crime, of national interest (Lyman 2003:26).

The data gathering phase implemented a pre-coded, closed-structured questionnaire with a typical 5-point, Rensis Likert-summated rating scale for ordinal measurement. Response calibration of a Likert-type scale is of special importance in attitude measurement, primarily to determine the degrees or latitudes of acceptance (strongly agree/ agree), non-commitment (uncertain) and rejection (disagree/strongly disagree) of the operationalised variables or statements contained in the questionnaire. Such latitudes constitute the essence of perceptions, opinions or attitudes (cf. Sherif, Sherif \& Nebergal 1965).

A non-probability sampling technique in the form of purposive (judgmental) sampling has been utilised during the data collection phase. Two medium-sized, rural towns in the Eastern Cape (previously the Republic of Transkei), viz: Mthatha and Butterworth have been arbitrarily selected as suitable research sites. An expected frequency $\left(f_{e}\right)$ of 250 questionnaires in respect of each town has been set. Four trained field workers (two for each town) have been appointed to hand-deliver and again recollect the questionnaires from the respondents (sampling units). All the field workers have obtained an undergraduate degree in Criminology at the Walter Sisulu University for Science and Technology (WSU) at Mthatha. They were not allowed to suggest any possible answers or outcomes to the questions or variables contained in 
the questionnaire and to refrain from attaching their own prejudices and/or viewpoints to the study in general. They were, however, free to clarify uncertain terms or words when required to do so. The selection of two separate research sites, in no way suggests that the present inquiry implies a comparative study. At the conclusion of the data collection phase, all the questionnaires were carefully edited. The observed frequency $\left(f_{0}\right)$ for Mthatha accounted for $168(56.0 \%)$ and for Butterworth 132 (44.0\%) responses. Data collection extended over a period of approximately five months, commencing in March 2008 during the first academic break and was concluded during the third week of July, more or less at the end of the second academic semester at the WSU. A combined response rate of $60.0 \%$ (both observed frequencies) has been achieved. Possible reasons for the somewhat low response rate could be attributed to: (a) a large quantity of the questionnaires contained insufficient information (especially in the case of Butterworth) which totally ruled out accurate codification, (b) an apparent careless attitude on the part of selected sampling units to complete and return their surveys, and (c) quite a number of the questionnaires have been lost through negligence on the part of some field workers (Table I). A tabular presentation of the demographic particulars of both samples is presented in Annexure A.

Table I Questionnaire distribution among two rural, Eastern Cape populations $(N=300)$

\begin{tabular}{lcccc}
\hline Research site & \multicolumn{2}{c}{ Expected frequency } & \multicolumn{2}{c}{ Observed frequency } \\
& $\mathbf{n}$ & $\%$ & $\mathbf{n}$ & $\%$ \\
\hline Mthatha & 250 & 50.0 & 168 & 56.0 \\
Butterworth & 250 & 50.0 & 132 & 44.0 \\
\hline Total & $\mathbf{5 0 0}$ & 100.0 & 300 & 100.0 \\
\hline
\end{tabular}

Statistical tests: Chi-square and level of significance

Pearson's Chi-square $\left(\chi^{2}\right)$, which is a test of the independence of the relationship between nominal (or categorical) variables, e.g. gender, and fear of crime has been utilised to determine if significant differences are present between independent and dependent variables and whether any observed statistical differences are due to sampling error or simply due to chance or that it is "... highly improbable that they [differences] have been due to sampling error and thus considered statistically significant at a given probability level” (Hagan 2000:38I). Chi-square is calculated according the following formula: $\chi^{2}=\Sigma\left[\left(f_{o}-f_{e}\right)^{2} / f_{e}\right]$. The level of significance has been set at $p \leq .05$ (unless indicated otherwise).

Data analyses were performed with the assistance of the Statistical Package for the Social Sciences (SPSS), version 15.0. The transfer of data from questionnaires to both data and variable files has been facilitated by means of keyboard entries using a coding sheet, especially designed for this purpose. This procedure was followed by a data cleaning process (cf. Hagan 2000) until a functional data deck has been obtained.

\section{Results}

It must be reiterated that no previous research (locally or abroad), has been undertaken to empirically assess the relationship between fear of crime and policing (per se) as a fear of crime reduction agent. It is, therefore, not the aim of the present study to unveil whether such relationship does indeed exist or not. The role of policing in the present context merely serves to complement the research question in a theoretical fashion. Table 2 reveals two levels of contact with the police: voluntary (positive) and involuntary (negative) contact. Voluntary contact entails situations where the respondents show their willingness to associate with the police while involuntary contact is not an option. Altogether 186 (62.0\%) of the total sample indicated no contact with the police. A frequency breakdown indicates that female respondents (I06 or $35.3 \%$ ) had no contact with the police compared to their male counterparts (80 or $26.7 \%$ ). It further transpires that 69 (23.0\%) of the sample had positive contact with the police (witness/informant) while 45 (I5.0\%) had negative encounters with the police (accused/suspect). Similarly, 16 (5.4) percent females were involuntarily involved with the police, while 29 $(9.7 \%)$ of the males had voluntary contact with the police. On the positive side, 45 (I5.0\%) female respondents had voluntary contact with the police, compared to $24(4.7 \%)$ males. No significant differences have been observed in the scores. 
Table 2 Type of contact with the police, by gender $(N=300)$

\begin{tabular}{|c|c|c|c|c|c|c|}
\hline \multirow[t]{2}{*}{ Type of contact } & \multicolumn{2}{|c|}{ Male } & \multicolumn{2}{|c|}{ Female } & \multicolumn{2}{|c|}{ Total } \\
\hline & $\mathbf{n}$ & $\%$ & $\mathbf{n}$ & $\%$ & $\mathbf{n}$ & $\%$ \\
\hline As accused/convicted & 5 & 1.7 & 3 & 1.0 & 8 & 2.7 \\
\hline As accused/acquitted & 13 & 4.3 & 5 & 1.7 & 18 & 6.0 \\
\hline Suspect and detained & $\mathrm{II}$ & 3.7 & 8 & 2.7 & 19 & 6.3 \\
\hline Witness - criminal case & 21 & 3.7 & 38 & 12.7 & 59 & 19.7 \\
\hline Informant to the police & 3 & 1.0 & 7 & 2.3 & 10 & 3.3 \\
\hline No contact at all & 80 & 26.7 & 106 & 35.3 & 186 & 62.0 \\
\hline Total & 133 & 44.3 & 167 & 55.6 & 300 & 100.0 \\
\hline
\end{tabular}

$(\mathrm{p} \geq .05)$

Table 3 Reporting crime to a police station when victim(s) are personally victimised, by gender $(\mathrm{N}=300)$

\begin{tabular}{|c|c|c|c|c|c|c|}
\hline \multirow[t]{2}{*}{ Response categories } & \multicolumn{2}{|c|}{ Males } & \multicolumn{2}{|c|}{ Females } & \multicolumn{2}{|c|}{ Total } \\
\hline & & $\%$ & $\mathbf{n}$ & $\%$ & $\mathbf{n}$ & $\%$ \\
\hline Always & 33 & 11.0 & 41 & 13.6 & 74 & 24.7 \\
\hline Often & 14 & 4.7 & 20 & 6.7 & 34 & 11.3 \\
\hline Sometimes & 48 & 16.0 & 41 & 13.6 & 89 & 29.7 \\
\hline Never & 38 & 12.7 & 65 & 21.7 & 103 & 34.3 \\
\hline Total & 133 & 100.0 & 167 & 55.6 & 300 & 100.0 \\
\hline
\end{tabular}

$(\mathrm{p} \geq .05)$

Asked whether respondents feel at liberty to report all crimes to the police, about one-third of all the respondents ( 103 or $34.3 \%$ ) indicated they would never visit a police station for that purpose, even if they are personally victimised (Table 3 ). In this regard, female respondents are somewhat more unwilling (65 or $21.7 \%$ ) than the males (38 or $12.7 \%$ ). Closer scrutiny of the raw scores reveals that the remaining two-thirds of the respondents would either report crime always (74 or $24.7 \%$ ), often (34 or $11.3 \%$ ) or sometimes ( 89 or $29.7 \%$ ) to the police. Female respondents are slightly more eager to always report crime to the police (4I or 13.6\%), compared to the males (33 or $11.0 \%$ ). The differences in perceptions are not significant $(p \geq .05)$.

Table 4 Respondents feel at liberty to call upon the police for assistance when personally victimised, by gender $(\mathrm{N}=300)$

\begin{tabular}{|c|c|c|c|c|c|c|}
\hline \multirow[t]{2}{*}{ Gender } & \multicolumn{2}{|c|}{ Yes } & \multicolumn{2}{|c|}{ No } & \multicolumn{2}{|c|}{ Total } \\
\hline & $\mathbf{n}$ & $\%$ & $\mathbf{n}$ & $\%$ & $\mathbf{n}$ & $\%$ \\
\hline Male & 83 & 27.7 & 50 & 16.7 & 133 & 44.3 \\
\hline Female & 106 & 35.3 & 61 & 20.3 & 167 & 55.7 \\
\hline Total & 189 & 63.0 & III & 37.0 & 300 & 100.0 \\
\hline
\end{tabular}

$(\mathrm{p} \geq .05)$

Table 4 reveals the extent to which respondents would feel at liberty to call upon the police to provide emergency services in the event of personal victimisation. In this regard, about two-thirds (I89 or 63.0\%) of the total sample $(\mathrm{N}=300)$ positively indicated such willingness. The remaining one-third (III or $37.0 \%)$ of the respondents are not prepared to facilitate mutual interaction with the police in cases of personal victimisation. Female respondents appear to be more inclined (106 or $35.3 \%$ ) to call upon police protection should danger strike, compared to their male counterparts ( 83 or $27.7 \%)$. The differences of opinion are not significant $(p \geq .05)$. 
Table 5 discloses data reflecting the extent to which all the respondents would be willing to honour their duty and obligation in respect of crime prevention, while Table 6 reveals the degree to which respondents would be willing to execute such obligation by means of physically assisting the police in their endeavours to combat crime and reduce people's fear of crime and, by doing so, take responsibility of becoming co-owners of safety and security in a typical proactive manner. Although the majority of the sample (I 70 or $61.2 \%$ ) would always or even often be willing to honour their duty to prevent crime, it seems that female respondents (29 or $10.4 \%$ ) are significantly less prepared to get involved in this task $(p=.020)$ than the males ( 12 or $4.3 \%)$. Just over half of the male respondents $(68$ or $24.5 \%)$ feel they should always be willing to prevent crime, and for this reason, they are slightly more aware of this obligation than females (62 or $22.3 \%$ ). However, females (4I or $14.7 \%$ ) would sometimes be more inclined than the males (26 or $9.4 \%$ ) to take up this duty. Table 6 shows more or less similar trends $(p \geq .05)$.

Table 5 Frequency distribution of respondents' attitudes towards their duty to prevent crime, by gender $(\mathrm{N}=278)$

\begin{tabular}{|c|c|c|c|c|c|c|}
\hline \multirow[t]{2}{*}{ Response or attitude } & \multicolumn{2}{|c|}{ Males } & \multicolumn{2}{|c|}{ Females } & \multicolumn{2}{|c|}{ Total } \\
\hline & $\mathbf{n}$ & $\%$ & $\mathbf{n}$ & $\%$ & $\mathbf{n}$ & $\%$ \\
\hline Always & 68 & 24.5 & 62 & 22.3 & 130 & 46.8 \\
\hline Often & 21 & 7.6 & 19 & 6.8 & 40 & 14.4 \\
\hline Sometimes & 26 & 9.4 & 41 & 14.7 & 67 & 24.1 \\
\hline Never & 12 & 4.3 & 291) & 10.4 & 41 & 14.7 \\
\hline Total & 127 & 45.8 & $|5|$ & 54.2 & $278^{2)}$ & 100.0 \\
\hline
\end{tabular}

(I) $\chi 2=11.625 ; 4 d f ; p=.020 ;$ (2) Uncertain/undecided score not calculated.

Present-day policing in South Africa faces a unique challenge when it comes to crime prevention and reducing people's fear of crime. People should be aware of the extent of crime in their respective provinces as well as the role the police have to fulfill - first, in preventing crime and second, detecting and investigating it. People should also understand the relationship between crime, fear of crime and policing within the framework of democratic principles. Therefore, people experiencing an overbearing and abusive police system, may believe that stricter institutional control (discipline) of police power would be an urgent consideration for policy-makers. On the other hand, people who are most fearful of crime may think that more police officers who are afforded more authority to address the criminal elements in society are necessary to more effectively protect law-abiding citizens, in an attempt to positively reflect on their fear of crime (Lyman 2003:24). Such views present a conflicting dichotomy. Democratic police effectiveness dictates to the police to be proactively responsive to both crime and fear of crime as well as reactively suppressing criminal behaviour through law enforcement (Lyman 2003:24).

Table 6 Frequency distribution of respondents' attitudes toward their responsibility to assist the police in crime prevention, by gender $(\mathrm{N}=282)$

\begin{tabular}{lcccccc}
\hline Response or attitude & \multicolumn{2}{c}{ Males } & \multicolumn{2}{c}{ Females } & \multicolumn{3}{c}{ Total } \\
& $\mathbf{n}$ & $\%$ & $\mathbf{n}$ & $\%$ & $\mathbf{n}$ & $\%$ \\
\hline Always & 81 & 28.7 & 88 & 31.2 & 169 & 59.9 \\
Often & 13 & 4.6 & 13 & 4.6 & 26 & 9.2 \\
Sometimes & 21 & 7.5 & 42 & 14.9 & 63 & 22.3 \\
Never & 8 & 2.8 & 16 & 5.7 & 24 & 8.5 \\
\hline Total & 123 & $\mathbf{4 3 . 6}$ & $\mathbf{1 5 9}$ & $\mathbf{5 6 . 4}$ & $\mathbf{2 8 2}$ & $\mathbf{1 0 0 . 0}$ \\
\hline
\end{tabular}

(I) ( $\mathrm{p} \geq .05)$ Uncertain/undecided score not calculated.

Whatever the institutional outcome, the police are statutorily called upon to protect and serve the public (Servamus et Servimus), 24 hours per day and seven days a week. To ensure efficiency in this regard "...the police must be responsive to the public's fear of crime while counterbalancing that response with a fair application of the law" (Lyman 2003:6). The police are often perceived as being too quick to rush to judgments, police response time may be too slow or even absent, do not care about public concerns relating to crime and fear of crime, are brutal and dishonest. Crime and fear of crime Inkanyiso, Jnl Hum \& Soc Sci 20I I, 3(I) 
are becoming continuing political issues used in national political campaigns and debates. Politicians often promise recruitment of more police officers, but "...no matter how many police officers are employed, citizens' fear of crime remains constant" (Lyman 2003:8).

Gender and fear of personal victimisation

Based on a three-pronged measuring scale, various researchers (Garofalo 1979, Toseland 1982, Glanz 1989 \& Van Velzen 1998) identified the gender-variable as the most powerful predictor of fear of personal victimisation. More particularly, female respondents appear to be more fearful than the males: (a) when walking alone in their neighbourhood at night, (b) being alone at their homes or apartments at night and (c) when visiting shopping centers/malls alone. Significant differences resulting from a cross-correlation between gender and fear of personal victimisation, are reported in Table 7.

Table 7 Gender and fear of crime $(\mathrm{N}=300)$

\begin{tabular}{|c|c|c|c|c|c|c|c|c|c|c|}
\hline \multirow[t]{3}{*}{ Measures of fear crime } & \multicolumn{4}{|c|}{ Feel safe } & \multicolumn{4}{|c|}{ Feel unsafe } & \multicolumn{2}{|c|}{ Total } \\
\hline & \multicolumn{2}{|c|}{ Male } & \multicolumn{2}{|c|}{ Female } & \multicolumn{2}{|c|}{ Male } & \multicolumn{2}{|c|}{ Female } & \multirow[b]{2}{*}{$\mathbf{n}$} & \multirow[b]{2}{*}{$\%$} \\
\hline & $\mathbf{n}$ & $\%$ & $\mathbf{n}$ & $\%$ & $\mathbf{n}$ & $\%$ & $\mathbf{n}$ & $\%$ & & \\
\hline Walking alone in neighbourhood at night & 30 & 10.0 & 16 & 5.3 & 103 & 34.3 & $|5|^{1)}$ & 50.3 & 300 & 100.0 \\
\hline Alone at home or apartment at night & 38 & 12.7 & 23 & 7.7 & 95 & 31.7 & $144^{2)}$ & 48.0 & 300 & 100.0 \\
\hline Visiting shopping centres alone & 36 & 12.0 & 26 & 8.7 & 97 & 32.3 & $|4|^{3)}$ & 47.0 & 300 & 100.0 \\
\hline
\end{tabular}

(I) Significant: $\chi 2=14.91$; 3df; $p=.002$; (2) Significant: $\chi 2=13.41$; 3df; $p=.004$; (3) Significant: $\chi 2=10.78$; $3 \mathrm{df} ; p=.013$.

A frequency distribution of the data shows positive relationships between gender and fear of crime as far as the following variables are concerned (Table 7):

- Walking alone in the neigbourhood at night causes females to feel significantly more unsafe and fearful ( $15 \mathrm{I}$ or $50.3 \%)$ than the male ( 103 or $34.3 \%)$ respondents $(p=.002)$.

- Female respondents are significantly more unsafe and fearful (I44 or $48.0 \%)$ of being alone at their homes/apartments during nighttimes, compared to their male counterparts ( 95 or $31.7 \%),(p=.004)$.

- Visiting shopping centres/malls alone tend to make female respondents (I4I or $47.0 \%)$ feel significantly more unsafe/ fearful than their male counterparts ( 97 or $32.3 \%),(p=.013)$.

These findings are congruent with that reported by other researchers, indicating that females are likely to be more fearful than males because they tend to feel more powerless and lack self-defense skills (Garofalo 1979, Toseland 1982:203), Glanz 1989 and Van Velzen 1998:107). All these empirically-based studies, the latter two are South African, confirm the expected: women are obviously more fearful of criminal victimisation than men, because of their apparent passive physical features and emotional vulnerability.

Table 8 Gender and personal fear of selected crimes $(N=300)$

\begin{tabular}{|c|c|c|c|c|c|c|c|c|}
\hline \multirow[t]{3}{*}{ Type of victimisation } & \multicolumn{4}{|c|}{ Most fearful } & \multicolumn{4}{|c|}{ Least fearful } \\
\hline & \multicolumn{2}{|c|}{ Male } & \multicolumn{2}{|c|}{ Female } & \multicolumn{2}{|c|}{ Male } & \multicolumn{2}{|c|}{ Female } \\
\hline & $\mathbf{n}$ & $\%$ & $\mathbf{n}$ & $\%$ & $\mathbf{n}$ & $\%$ & $\mathbf{n}$ & $\%$ \\
\hline Murdered at home/apartment & 97 & 32.3 & 146 & 48.7 & 31 & 10.3 & 29 & 9.7 \\
\hline Being raped & 27 & 9.0 & 139 & $46.3^{1)}$ & 106 & 35.3 & 28 & 9.3 \\
\hline Assault (with serious injuries) & 85 & 28.3 & 144 & $48.0^{2)}$ & 48 & 16.0 & 23 & 7.7 \\
\hline Armed robbery & 90 & 30.0 & 150 & $50.0^{3)}$ & 33 & 11.0 & 17 & 5.7 \\
\hline Vehicle hijacking & 103 & 34.3 & $|4|$ & 47.0 & 30 & 10.0 & 26 & 8.7 \\
\hline Vehicle stolen & 94 & 30.0 & 140 & $46.7^{4)}$ & 39 & 13.0 & 27 & 9.0 \\
\hline Property stolen & 83 & 27.7 & 133 & $44.3^{5)}$ & 49 & 16.3 & 34 & 11.3 \\
\hline
\end{tabular}

(1) Significant: $\chi 2=152.890 ; 3 \mathrm{df} ; p=.000$; (2) Significant: $\chi 2=22.316$; 3df; $p=.000$; (3) Sig.: $\chi 2=27.147 ; 3 \mathrm{df} ; p=.000$;

(4) Significant: $\chi 2=8.029 ; 3 \mathrm{df} ; p=.045$; (5) Significant: $\chi 2=11.944 ; 3 \mathrm{df} ; p=.018$. 
The respondents have rated those crimes they fear most and those they fear less, in Table 8 . Data indicate that female respondents are disproportionately more fearful than males of all the crimes listed in the table. Although females fear murder (I46 or 48.7\%) and rape (139 or 46.3\%) significantly more than the males (97 or $32.3 \%$ and 27 or $9.0 \%$ respectively). Whereas Van Velzen's study (1998:107) discloses a higher rating for fear of rape $(\mathrm{F}=432.6 \mathrm{I})$ by female respondents than for murder $(F=347.15)$, the present study reveals an inverse rating for these type of crimes. Data show that armed robbery at their residential premises, in neighbourhoods and in shopping centers (see Table 7) is the type of crime significantly feared most by female respondents (I50 or $50.0 \%$ ) compared to males $(90$ or $30.0 \%)-p=.000$ ). Armed robberies at shopping centers (especially jewellery stores and ATMs) usually receive high profile coverage in the written and electronic media because of: (a) the use of sophisticated weapons during such raids (like R5's, AK 47's, semiautomatic pistols and even explosives in the blowing-up of automatic transmission machines), and (b) the violent nature of such robberies which, more than often, ends up in a shoot-out with the police resulting in loss of human lives.

Assault to inflict grievous bodily harm also appears to be of much greater concern to female respondents (I44 or $48.0 \%$ ) than it is to males ( 85 or $28.3 \%$ ). This difference is significant $(p=.000)$. Women abuse appears to be widespread in South Africa and although this type of crime is not separately provided for in the annual police statistics, it is included in the category assault with the intent to inflict grievous bodily harm which show an increase of $0.7 \%$ (compared to the previous year, 2008-09) or 'common assault' which increased by $2.3 \%$ (www.saps.gov.za/statistics/reports/crimestats/ 2010). It should also be noted that sexual assault and rape of a male person by another male person now statutorily qualifies as 'male rape' in terms of the Criminal Law (Sexual Offences and Related Matters) Amendment Act, no. 32 of 2007 (cf. Booyens 2008). Having their motor vehicles $(p=.045)$ and property stolen $(p=.018)$ also produced significant differences in opinion by female respondents, compared to the males. Vehicle hijacking appears to be of great concern to both male ( 103 or $34.3 \%$ ) and female ( $14 \mathrm{I}$ or $47.0 \%)$. This difference is not significant ( $\mathrm{p} \geq .05)$.

\section{Prevention of crime and fear of crime}

Bayley (1994:123-142) asserts that policing in the United States did not always satisfy people's expectations about crime prevention and the reduction of fear of crime, simply because the "... police do not prevent crime. This is one of the best kept secrets of modern life. Experts know it, the police know it, but the public does not know it" (Bayley 1994:3). The same observation may perhaps be true for contemporary policing in South Africa, because of the apparent absence of acceptable proactive measures in the form of visible role fulfillment; both as far as crime control and crime prevention are concerned. Just as criminal victimisation by means of armed robbery becomes more violent, so the police react with more vigour in terms of Section 49 of the Criminal Procedure Act (Act 55 of 1977), by reverting to 'shoot-to-kill'practices.

Police crime statistics for I April 2009 till 3I March 2010, released during September 2010, clearly show modest decreases in certain crime categories such as murder (-7.2\%), attempted murder (-4.9\%), armed robbery (-6.3\%), and all categories of sexual offences (-3.1\%). During the same statistical period, however, 'residential (house) robbery' increased by $1.9 \%$ and robbery at business premises with $4.4 \%$ (www.saps.gov.za/statistics/reports/crimestats/20/0/ crime_stats.htm).

It would appear that increasing police numbers do not visibly affect prevailing crime rates because criminals are capable of changing their modus operandi, sporadically. Further, the application of Section 49 of Act 55 of 1977 (right to kill) by the South African Police Service (SAPS) to curb prominent violent crimes, do apparently not show the desired effects. Police statistics released by the Independent Complaints Directorate (ICD) show that fatal violence on the part of the police, increased with $102 \%$ over the past five years. This observation may have caused great concern among government officials and the broader public - perhaps because of the police's "...shoot first"-interpretation of Section 49 of the Criminal Procedure Act. It may have also served as some kind of 'motivation' to subordinates to answer 'fire' with 'fire' (Beeld 2010:8).

National Commissioner, General Bheki Cele, further justifies his decision by indicating that criminals do not carry broomsticks or sjamboks (Sunday Tribune 2010:I). And yet, the public still remain concerned about shoddy police work in the form of inadequate criminal investigations owing to inefficiency that deprives the optimal functioning of the necessary criminal justice processes (Sunday Tribune 2010:3I). Worldwide, police are obliged to maintain law and order in a democratic fashion by not killing suspects before they could be held accountable in a court of law. The first ten months of 2010 already show that the SAPS have shot and killed 257 people during the arrest-stage compared to 20082009 (+20.1\%). People shot and killed in the act by the police during the same period has, however, shown a slight decrease of $3.8 \%$ (Beeld 2010:8).

It is often argued that communities deserve the crime that prevails in their particular police jurisdictions, simply because of a lack of constructive police crime prevention strategies like random street patrolling. Police role visibility Inkanyiso, Jnl Hum \& Soc Sci 20I I, 3(I) 
provides symbolic protection to people and creates opportunities to deter would-be law violators, thereby lowering people's fear of crime because of its proactive inclination and the fostering of the 'police-are-omnipresent-illusion' in the minds of law-abiding citizens (Lyman 2003:23-24).

\section{A need for balance?}

Fear of crime persists as a social concern and is more than often intensified by media reports about crime. Mindful of the shortcomings of the criminal justice system and its processes, media hype portraying violent crime scenes, for instance, may perhaps further exacerbate people's skepticism about the abilities of the police to successfully deal with crime and the fear of crime among innocent law-abiding citizens. On the other hand, fear of the police (as the protectors of human rights) and their involvement in serious law violations such as the abuse of power and authority, showing disrespect for human dignity, etc., on the other hand, may even further increase people's fear of crime. Continual media bombardment of police inefficiency may contribute towards inducing people into believing that they are indeed not up to the successful execution of their obligations relating to the democratic maintenance of law and order and may thus easily overshadow the heroic deeds of the police.

The police feel that the public are quick to point fingers at them, apparently for being ignorant when it comes to attending to calls for police service, being brutal and dishonest, unable to police themselves, abusing their power and authority, having been accorded too much discretion under minimal control and supervision, being involved in large scale corruption, nepotism, etc, (Lyman 2003:25-28). Having been transformed into a democracy may elicit public expectations of a disciplined and efficient policing system under the auspices of bureaucratic rules, primarily designed to avoid any similarities with a police state.

\section{Conclusions}

Since 27 April 1994, South Africans are living in a free society; not only free from police and government oppression, but also free of criminal victimisation and fear of crime, because "...[w]ith freedom, all democrats know, comes responsibility" (Sowetan 2010:16). Members of the public are dependent upon a police institution that is capable of ensuring their safety and security as well as the fair and impartial enforcement of the laws of the country, firmly based on constitutional principles.

Gender has emerged as the most powerful predictor of fear of personal victimisation and for obvious reasons, female respondents appear to be considerably more fearful than their male counterparts, whether alone at home at night, in the neighbourhood or whilst doing shopping at shopping malls. The findings of the present study therefore partially supports previous findings in this regard (Cf. Van Velzen 1998), with the exception that women fear murder (48.7\%) more than rape $(46.3 \%)$, apparently because of the fatal nature accompanying armed robbery-attacks at residential premises usually after midnight. The present study merely outlines the nature and extent of fear of crime and the role the police to ease the public's concerns about their safety and security. Every possible precautionary measure to prevent and keep the escalation of serious crime under control should be seen as a step in the right direction. Police force is a necessary ingredient of efficient policing, but should be 'blended' with a fair balance of police service where members of the public could assist the police in the prevention of crime and fear of crime, either through Sector Policing or attending Community Police Forums (CPF's).

\section{References}

Alant, C.J., Lamont, A.M., Maritz, F.A. \& Van Eeden, I.J. I98I. On societies and societal existence. Johannesburg: McGraw-Hill.

Bayley, D.H. 1994. Police for the future. New York: McGraw-Hill.

Beeld. 2010. Dodelike geweld deur polisielede neem skerp toe, 6 November: 8.

Booyens, K. 2008. The sexual assault and rape of male offenders and awaiting-trial detainees. Unpublished doctoral thesis. Pretoria: University of Pretoria.

Garofalo, J. 1979. Victimization and the fear of crime. Journal of Research in Crime and Delinquency, 16: 80-87.

Glanz, L. 1989. Coping with crime: The South African publics' perceptions of and reactions to crime. Unpublished research report. Pretoria: Human Sciences Research Council (HSRC).

Hagan, F. 2000. Research methods in Criminology and Criminal Justice. $5^{\text {th }}$ Edition. Belmont, California: Allyn \& Bacon.

Huysamen, G.K. 1994. Methodology for the social and behavioural sciences. Halfway House, Midrand (Gauteng): Southern Books. Lyman, M.D. 2003. The police: An introduction. Simon \& Schuster, Prentice Hall: New Jersey.

Lynch, V. 20I0. DNS-voorlegging deur SA vrou ontstel afgevaardigdes. Beeld, 22 October: 2.

Mayoyo, L.E. 2009. The police as a fear of crime reduction agency in two rural communities. Unpublished M.A. dissertation. KwaDlangezwa: University of Zululand.

Moore, M.H. \& Trojanowicz, R.C. 1988. Policing and fear of crime. The National Institute of

Justice (NIJ): Theme: Perspectives on Policing. United States Department of Justice. Monograph 3: I-7. Washington: United States of America.

Rapport. 2010. Duisende misdadigers word nooit gevang nie, 12 September: 6. 
Sherif, C.W., Sherif, M. \& Nebergal, R.E. 1965. Attitude and attitude change. Philadelphia: W.B. Saunders.

South Africa. 1977. The Criminal Procedure Act (Act 55 of 1977). Pretoria: Government Printer.

South African Police Service. 2010. The crime situation in South Africa: Crime statistics. April 2009 - March 2010. Accessed online on Septrember 14, 2010, at: http://www. saps.gov.za/statistics/reports/crimestats/2010/crime_stats.htm.

Sowetan. 2010. Abusing our democracy, 22 October: 16.

Steenkamp. L. 2009. Polisie verswyg 147 misdade. Beeld, I 5 October: 7.

Sunday Tribune. 2010. It's war! I4 November: I.

Sunday Tribune. 2010. Overhaul the justice system, I4 November 2010: 31

The Mercury. 2008. Fiery death as mobs rampage, I9 May: I.

The Star. 2008. Fearful crowd takes refuge in Jo'burg church, 19 May: 3.

The Times. 2008. Why are we failing to beat crime? I 3 August: 12.

Toseland, R.W. 1982. Fear of crime: who is most vulnerable? Journal of Criminal Justice 10: 199-209.

Van der Westhuizen, J. 1977. An introduction to criminological research. Pretoria: University of South Africa.

Van Heerden, T.J. 1982. Introduction to Police Science. Pretoria: University of South Africa.

Van Velzen, F.A. 1998. Fear of crime: A socio-criminological investigation. Unpublished doctoral thesis. KwaDlangezwa: University of Zululand.

What, Where, When (WWW) in the Zulu Kingdom. 2009. The Official Guide to Events, Shopping, Dining, Culture \& Entertainment. Issue 36 August-September 2009. Durban: Logo Graphics. 
